\title{
кУЛЬТУРОЛОГІя
}

УДК 351.746. (477) «1920-1980»

\author{
Вєдєнєєв Дмитро Валерійович, \\ доктор історичних наук, професор, професор \\ кафедри гуманітарних дисциплін Національної \\ академії керівних кадрів культури і мистецтв \\ zastava67@i.ua
}

\section{ПОЛІТИКА РАДЯНСЬКОЇ ДЕРЖАВИ ІЗ ЗНИЩЕННЯ ПРАВОСЛАВНИХ ХРАМІВ В УКРАЇНІ: МЕХАНІЗМ ТА ДУХОВНО-КУЛЬТУРНІ НАСЛІДКИ (1920-ті - 1965 рр.)}

Мета роботи. Дослідження згубних духовно-культурних наслідків цілеспрямованого знищення (закриття) православних культових споруд як одного із напрямів політики державного атеїзму в Українській РСР, розкриття ідейно-політичних та державно-адміністративних складових механізму кампаній по ліквідації храмів як цінної складової історико-культурної спадщини. Методологія. Стаття побудована на історичному і логічному гносеологічних підходах, застосовується комплекс загальнонаукових методів дослідження у сукупності із методами історичної науки, культурології та інших соціогуманітарних наук. Зокрема, використовуються структурно-функціональний, історико-генетичний, історико-порівняльний, кліометричний, крос-культурний, історико-правовий методи дослідження. Наукова новизна. Обумовлена спробами автора на підставі аналізу документальних першоджерел комплексно розглянути основні етапи (кампанії), нормативнорозпорядчу основу та організаційно-адміністративний механізм політики із знищення православних духовноархітектурних споруд (храмів, монастирів та інших об'єктів національної духовно-культурної спадщини) як структурно-функціональну складову курсу державного атеїзму, форму релігійного переслідування та утисків свободи сумління в Україні. Висновки. В основу комуністичної моделі відносин із Православ'ям було покладено витіснення Церкви з усіх сфер суспільного життя будь-якими засобами. Різко негативне ставлення радянської влади до Церкви залишалось незмінним по суті упродовж усього існування СРСР, хоча й мало різні форми, в залежності від зовнішнього та внутрішнього становища держави, політичної волі його керівників. Діяльність державних структур із руйнування храмів базувалася на цілеспрямованих ідеологізованих рішеннях керівних органів Комуністичної партії та вищих державних органів. Кампанії із знищення храмів, як правило, корелювалися із гоніннями на віру, православний клір та мирян, співпадали із репресивними заходами проти релігійних громад в СРСР та Українській РСР. Знищення храмів або перетворення їх на цивільно-господарські та інші споруди не за призначенням одночасно завдавало непоправного удару по духовно-культурній спадщині, адже культові споруди виступали органічною складовою вітчизняної історії, культури, основою культурноцивілізаційної традицій та одним із базових маркерів історико-культурної пам'яті.

Ключові слова: Духовне життя, Православна церква в Україні, церковна архітектура, історикоархітектурна спадщина, історія культури, державний атеїзм, державно-церковні відносини.

Веденеев Дмитрий Валерьевич, доктор исторических наук, професор, професор кафедры гуманитарных дисииплин Национальной академии руководящих кадров культуры и искусств

Политика советского государства по уничтожению православных храмов в Украине: механизм и духовно-культурные последствия (1920-е - 1965 гг.)

Цель работы. Исследование губительных духовно-культурных последствий целенаправленнго уничтожения (закрытия) православных культовых уоружений как одного из направлений политики государственного атеизма в Украинской ССР, раскрытие идейно-политических и государственноадминистративных составляющих механизма кампаний по ликвидации храмов как ценной составляющей историко-культурного наследия. Методология. Статья построена на историческом и логическом гноссеологических подходах, используется комплекс общенаучных методов исследования в совокупности с методами исторической науки, культурологии и других социогуманитарных наук. В частности, используется структурно-функциональный, историко-генетический, сравнительно-исторический, клиометрический, кросскультурный, историко-правовой методы исследования. Научная новизна. Обусловлена попыткой автора на основании анализа документальных первоисточников комплексно рассмотреть основные этапы (кампании), нормативно-распорядительную основу и организационо-административный механизм политики по уничтожению православных духовно-архитектурных сооружений (храмов, монастырей и других объектов национального духовно-культурного наследия) как структурно-функциональной составляющей курса государственного атеизма, формы религиозного преследования и притеснений свободы совести в Украине. Выводы. В основу коммунистической модели отношений с Православием было положено вытеснение Церкви

(С) Вєдєнєєв Д. В., 2019 
изо всех сфер общественной жизни любыми способами. Резко негативное отношение советской власти к Церкви оставалось неизменным по сути в течение всего существования СССР, хотя и имело различные формы, в зависимости от внешнего и внутреннего положения страны, политической воли его руководителей. Деятельность государственных структур по разрушению храмов базировалась на целенаправленных идеологизированных решениях руководящих органов Коммунистической партии и высших государственных органов. Кампании по уничтожению храмов, как правило, корелировались с гонениями на веру, православный клир и мирян, совпадали с репрессивными мероприятиями против религиозных общин в СССР и Украинской ССР. Уничтожение храмов или превращение их в государственно-хозяйственные и другие сооружения не по назначению, одновременно наносило непоправимый удар по духовно-культурному, поскольку культовые сооружения выступали органичной составляющей отечественной истории, культуры, основой культурноцивилизационной традиции и одним из базовых маркеров историко-культурной памяти.

Ключевые слова. Духовная жизнь, Православная церковь в Украине, церковная архитектура, историкоархитектурное наследие, история культуры, государственный атеизм, государственно-церковные отношения.

Viedienieiev Dmytro, Doctor of Historical Sciences, Professor, Professor of the Department of Humanitarian Scienses at the National Academy of Cultural and Arts Management

The Soviet state Policy aimed to Destruction of the Orthodox Churches in Ukraine: Mechanism and spiritual-cultural Consequences (1920 - 1965 years).

Goal. The study of the pernicious spiritual-cultural consequences of the targeted destruction (closing) of the orthodox religious buildings as one of the policy direction of the state atheism in Ukrainian SSR, the disclosing of the ideological-political and state-administrative components of the campaign mechanism aimed to liquidate the churches as the valuable component of the historical-cultural heritage. Methodology. The article is based on the historical and logical epistemological approaches, the author uses the complex of the general scientific methods with the methods of historical science, cultural studies and other social-humanitarian sciences. In particular, the structural-functional, historical-genetic, historical-comparative, cliometric, cros-cultural, historical-legal methods are used. The scientific novelty. The author based on the analysis of the documental sources makes an attempt to complex consideration of the main stages (campaigns), regulatory framework and organizing-administrative policy mechanism aimed to destruction of the orthodox spiritual-architects buildings (churches, monasteries and other objects of the national spiritual-cultural heritage) as the structural-functional component of the state atheism, the form of the religious persecution and oppression of conscience freedom in Ukraine. Conclusions. The basis of the communistic relations model with Orthodoxy constituted from the displacement of the church from the all spheres of the social life by the any ways. Sharply negative attitude of the Soviet government to the church remained unchanged during the all USSR existence, however it had the different forms depends on the external and internal state position, political will of its leaders. The state structures activity for the destruction of the churches based on the purposeful ideological solutions of the leading organs of Communist party and headed state organs. Campaigns for the churches destruction, as a rule, correlated with the persecutions of faith, orthodox clergy and laity, coincided with the repression measures against the religious groups in USSR and Ukrainian SSR. The churches destructions or its transfiguration to the civil-households and other buildings not for its purpose in the same time delivered an irreparable blow to the spiritual-cultural heritage, because the religious buildings were the organic component of the domestic history, culture, the basis of the cultural-civilization traditions and one of the main marks of the historical-cultural memory.

Keywords. The spiritual life, the Orthodox church in Ukraine, the church architecture, historical-architectural heritage, the history of culture, state atheism, state-religious relations.

Актуальність теми дослідження. Православна Церква як один з базових духовно-культурних інститутів українського суспільства, що упродовж тривалого часу виконувала роль домінуючого духовного чинника, опинилась в епіцентрі воєнно-політичних катаклізмів Першої і Другої світових воєн, революційних потрясінь, репресивної політики офіційно атеїстичної радянської влади, злочинів гітлерівських окупантів. Дослідження нищення сакральних православних споруд допомагає зрозуміти й усебічно дослідити цілеспрямований процес руйнування церкви в Україні радянської доби, ідеологічну й адміністративну складові політики державного атеїзму як елементу комуністичного будівництва, iї культурно-історичні наслідки

Аналіз досліджень і публікацій. Ідейно-політичне обгрунтування, організація та особливості проведення радянською державою кампаній із закриття православних храмів (особливо інтенсивних у періоди 1920-1941-х рр. та за часи т.зв. «хрущовських гонінь» кінця 1950-х - 1964 рр.) досліджувалося сучасними українськими істориками в монографічних, дисертаційних, науководокументальних працях, поява яких безпосередньо пов'язана із помітною активізацією досліджень трагічної долі Православної церкви в радянський період історії України, вивченням проблеми незаконних репресій та поглибленим студіюванням особливостей державо-церковних відносин у 1917-1991 pp. із енергійним залученням величезного масиву раніш недоступних науковцям документів. Передовсім, доцільно назвати низку узагальнюючих наукових праць 3 історії відносин радянської держави і Православної церкви в цілому або в окремі періоди радянської доби, ідейно- 
політичної основи утисків Церкви (з-поміж яких відомі дослідники минулого Церкви в Україні В.Баран, І.Грідіна, О.Вишиванюк, В.Войналович, В.Сленський, А.Киридон, І.Меркатун, В.Пащенко, В.Силантьєв та інші) $[6,10,11,13,14,16,17,21,22,28]$. Ряд досліджень (В.Верига, О.Ігнатуша, О.Нестуля, В.Силантьєв, О.Тевікова та інші) $[8,15,18,29,30]$ безпосередньо висвітлюють перебіг кампаній із закриття храмів, вилучення церковного майна та долі церковної духовно-культурної спадщини. Значну увагу вивченню процесу знищення храмів та богослужбового начиння приділено у спеціальних дослідженнях щодо незаконних репресій в релігійному середовищі Української РСР (передовсім варто виділити підготовлені на солідному архівному матеріалі праці Л.Бабенко, О.Бажана, Н.Рубльової), а також в узагальнюючих працях з історії політичних репресій в Україні $[1,2,3,4,5,23,24,27]$. На основі солідного обсягу документальних першоджерел порушена проблема висвітлена у роботах відомих на пострадянському просторі дослідників історії Православної Церкви радянських часів О.Васильєвої, М.Одинцова, прот. В.Ципіна, М.Шкаровського [7,19,20,33,34, 35].

Мета дослідження. Наукова реконструкція механізму та перебігу руйнування православних культових споруд (включаючи об’єкти національної культурно-історичної спадщини) як складової політики державного атеїзму в СРСР.

Виклад основного матеріалу. Християнський храм, у відповідності до релігійної семантики, це - місце перебування Бога і місце зібрання віруючих для поклоніння і молитви. Назва храму грецькою - «киріакон» перекладається як «житло Господнє». Водночас храм уособлює собою модель Всесвіту, спрямованого рухатися шляхом спасіння, трактується як «корабель спасіння». Часто храм був $\mathrm{i}$ витвором мистецтва, центром культурного життя, скарбницею мистецьких творів. Руйнування храму 3 погляду настанов політики державного атеїзму (яка офіційно запроваджується радянським урядом 3 1918 р.) не тільки усувало фізичні можливості для вільного віросповідування, проповіді слова Божого й організації церковної громади, але й вивільняло духовно-інформаційний простір для насадження постулатів офіційної ідеології та формування нового морально-культурного клімату у суспільстві.

Слід сказати, що напередодні Першої світової війни та революційних подій 1917 року християнство в Російській та Австро-Угорській імперіях являло собою потужну духовну й суспільну силу. Зокрема, у Російській імперії православ'я (Російська Православна Церква, РПЦ) виступало офіційною релігією й нараховувало до 125 млн. віруючих (до 70\% населення), понад 130 єпископів, 120 тис. священників, дияконів та псаломщиків, 107 тис. монахів та послушників, які служили або молилися у 67 єпархіях, у понад 78 тис. храмах й каплицях, 1256 монастирях. Існувало 4 духовні академії, 62 духовні семінарії, 185 духовних училищ [32, ф. 1, оп.23, спр. 1642, арк.14].

В основу партійно-державної політики по відношенню до релігії, Церкви, віруючих було покладено відомий декрет Ради Народних Комісарів (РНК, уряду) Радянської Росії від 23 січня 1918 p. «Про відокремлення церкви від держави і школи від церкви». Його зміст майже повністю був повторений декретом Тимчасового Робітничо-Селянського уряду України від 22 січня 1919 р. 8 травня 1918 р. Наркомат юстиції утворив VIII відділ з реалізації норм по відділенню церкви від держави та школи від церкви. Практична й цілеспрямована реалізація антирелігійної політики (як постійної складової діяльності радянської держави) розпочалась в Україні після закінчення громадянської війни. 1 червня 1921 р. у складі Наркомату юстиції було створено так званий «ліквідаційний відділ». Через деякий час постановою законодавчого органу - Всеукраїнського центрального виконавчого комітету (ВУЦВК) від 6 вересня 1922 р. відділ передали до Наркомату внутрішніх справ (НКВС) УРСР [31, ф. 8, оп. 1, спр. 873, арк. 138].

Хоча закриття церков на початку 1920-х рр. набирало обертів, центральна влада, як у Москві, так і у Харкові, все ще діяла обережно, розуміючи, що брутальне втручання у патріархальну свідомість селянства може бути небезпечним для існування самої влади. Обіжники ВУЦВК та НКВС від 14 серпня 1924 р. та НКВС від 26 серпня 1924 р. встановлювали порядок закриття молитовних будинків, однак на місцях допускалися чисельні порушення. У цей час кампанія по вилученню церков у сільських громад здебільшого була пов'язана з ініціативою місцевих органів влади. Архівні документи свідчать про те, що у першій половині 1920-х рр. навіть траплялись випадки повернення віруючим реквізованих у них церков [31, ф. 5, оп. 2, спр. 194, арк. 17].

Проте, вже наприкінці 1920-х рр. партійно-державна політика щодо церкви здійснювалася у відповідності до концепції «загострення класової боротьби по мірі будівництва соціалізму в СРСР». «Силовий» тиск на Церкву було фактично санкціоновано надісланою з Москви на початку 1929 р. директивою, у якій релігійні організації оголошувались єдиною контрреволюційною силою [14, c.13]. 29 грудня 1929 р. НКВС УРСР затвердив Положення «Про порядок організації, діяльності, звітності і ліквідації релігійних громад та систему обліку адміністративними органами складу релігійних громад та служителів культу» [25]. Документом, по суті, затверджувався типовий статут 
релігійної громади, визначався порядок ліквідації релігійної громади та закриття молитовних будинків.

Керівні органи КП(б)У упродовж 1929-1930 рр. ініціювали масові закриття церков, руйнацію храмів, у тому числі всесвітньовідомих пам'яток історії та культури. Динаміка закриття церков залежала від загального наступу «соціалізму по всьому фронту». Потужний поштовх закриттю релігійних споруд надала форсовані індустріалізація, колективізація, прискорена «культурна революція» в СРСР. У лютому 1930 р. ВЦВК і РНК СРСР ухвалили постанову «Про боротьбу 3 контрреволюційними елементами у керівних органах релігійних об'єднань», що підштовхнуло новий наступ на релігійну сферу. Тоді знищили до половини 350 тис. православних храмів та молитовних домів, заарештували до 40 тис. священнослужителів (у т.ч. понад 30 архієреїв).

На початку 1930-х рр.. у Києві, який разом з передмістям мав до революції до 30 тис. представників духовенства и монахів, 130 лише православних храмів и молитовних будинків [12, ф.9, спр. 74, арк. 87], служіння відправлялось лише у 12 храмових спорудах. Інші церкви стояли закритими, або були переобладнані під різні склади, антирелігійні заклади. 8 монастирів та більше, ніж як три чверті парафіяльних храмів не діяли. Одну з найбільших православних святинь українців Києво-Печерську Лавру перетворили під так зване «музейне містечко» (а до 1929 р. - закрили відповідно до рішення Політбюро ЦК КП(б)У). Софійський собор відвели під «державний заповідник». У Микільсько-Слупському монастирі розмістили кравецьку артіль, у Володимирському соборі - Музей антирелігійної пропаганди.

Однак безпосереднє масове нищення київських церков відбулось тоді, коли вирішувалось питання перенесенням до Києва у 1934 р. столиці УРСР. Саме у той час були підірвані перлини українського бароко Микільський військовий та Михайлівський Золотоверхий собори, Успенський та Богоявленський собори на Подолі, інші церковні споруди, які були визнаними пам'ятками української культури. Згідно із офіційними документами, за період з 1 жовтня 1929 р. до 1 жовтня 1930 р. на території України з дотриманням усіх формальностей законодавства було закрито 379 молитовних будинків, із них православних - 260. Без санкцій ВУЦВК закрили майже вдвічі більше: 719, а загалом 1098 молитовних будинків [16, с. 297-298].

Вище керівництво вимагало проводити активнішу культурно-освітню й пропагандистськоагітаційну роботу, «якнайширше втягуючи... всю радянську громадськість» в ініціювання та підтримку кампанії закриття церков [31, ф.1, оп. 5, спр. 27, арк. 81], визначало необхідний процент підписів населення для закриття молитовень тощо. Виконуючи вказівки центру чи вдаючись до самовільних дій, функціонери на місцях складали списки (які не відповідали дійсності) «за закриття молитовних будівель», або збирали підписи населення, вдаючись до погроз, шантажу, арештів, накладання штрафів [31, ф.1,оп. 7, спр. 179, арк. 273].

Одним із поширених засобів закриття храму, або принаймні недопущення проведення богослужінь було навмисне (з боку влади) розірвання угоди між райвиконкомами чи сільрадами та громадами на користування храмом через несплату податків, які щоразу збільшувались. У першу чергу це застосовувалось до кафедральних соборів, навколо яких найбільше зосереджувалось життя церковних громад. За даними дослідників, з 1931 р. по квітень 1936 р. в Україні закрили щонайменше 5170 церков. Реально ж припинив діяльність 8541 молитовний будинок, станом на 1 квітня 1936 p. 3371 храм не діяв, формально не вважаючись закритим [15, с. 34].

На Вінниччині, Донеччині, Кіровоградщині, Миколаївщині, Сумщині, Хмельниччині, не лишилось жодної православної церкви, а на Луганщині, Полтавщині, Харківщині діяло по одному храму. Із припиненням діяльності церкви закінчувала існування й релігійна громада, парафія, яка традиційно була основою конфесійної структури в православ'ї.

Відібрані храми тривалий час стояли зачиненими, але здебільшого використовувалися як клуби, бібліотеки, театри, музеї, інші культурно-освітні заклади, нерідко - під колгоспні комори та зерносховища, склади тощо. Спочатку акції перетворення храмів на «культурні установи» здійснювали переважно в містах та селищах міського типу, районних центрах, у робітничому середовищі. Таку практику було апробовано вже в першій половині 1920-х рр. Вона супроводжувалася насадженням ідеологізованих культів: урочистими зборами, проголошенням доповідей, виконанням «Інтернаціоналу», масовими гуляннями, «комсомольськими обрядами» тощо. Згодом подібні сценарії поширилися й у сільській місцевості.

Не випадково одним із аргументів закриття храмів у 1932-1933 рр. було закриття церков через необхідність їх використання для зберігання врожаю. Саме 31933 р. масовим явищем стало перетворення релігійних споруд під зерносховища.

Окремо варто виділити нечувані гоніння на Церкву в період Великого терору 1936-1938 pр. Як доповідав НКВС СРСР Й.Сталіну, лише у серпні-листопаді 1937 г. арештували 166 єпископів РПЦ (з 
них репресували 81, у т.ч. до 60 розстріляли), 9116 священників (репресували 4629), 2173 монахів (934), а всього за цей період арештували 31359 «церковників и сектантів» (3 них до 6,5 тис в УРСР) [1, с.23] У 1939 р. на свободі залишалося чотири правлячих архієрея РПЦ, і ще кілька служили простими священиками.

У період з 1 червня 1937 р. до 4 січня 1938 р. 3-поміж 177350 заарештованих в УРСР «ворогів народу» нараховувалося 7245 представників «церковно-сектантської контрреволюції», 3 яких до 4 січня 1938 р. 6112 осіб було засуджено позасудовими органами НКВС УРСР. До липня 1938 р. ця категорія жертв беззаконня поповнилася 1587 арештованими [4, с.18].

Трагічна доля православних храмів мала вплив на релігійну свідомість, викликаючи культурний бунт, активізацію парафіяльного життя, намагання протидіяти вандалізму (захистити храм, а коли не вдавалося - зберегти його реліквії).

3 початком війни та окупацією території України, релігійна політика нацистів в окупованих областях визначалась загальним ставленням до слов'янських народів як «неповноцінних», а також створенням перешкод на шляху до формування будь-яких об'єднуючих релігійних центрів. Водночас окупанти цілеспрямовано впливали на конфесійну ситуацію в Україні для досягнення своїх воєннополітичних цілей, керуючись принципом «поділяй і володарюй». Із кон'юнктурною метою вони допускали відкриття храмів, але згодом завдали варварського удару по релігійним спорудам. За неповними даними Надзвичайної державної комісії, окупантами було знищено, пограбовано й спаплюжено 1670 церков, 237 костьолів, 59 синагог, і 258 інших релігійних споруд [19, с. 368-369].

Оскільки нацистський режим був ворожим християнству в цілому й культивував у Рейху антигуманні, містичні, окультні погляди як основу «нової віри», увага окупантів до «церковного питання» пояснювалася бажанням використати місцеві релігійні об'єднання для зміцнення позицій німецької адміністрації та підриву лояльності населення до радянського ладу. Почалося відкриття храмів, закритих у 1930-х роках радянською владою. У Сталінській обл. кількість православних громад сягала близько 300 .

Показово змінилась релігійна ситуація під час нацистської окупації у Вінницькій області - тут відкрили 822 церкви (найбільше серед усіх областей України). На момент звільнення області у березні 1944 р. у Вінницькій єпархії діяли 839 церковних громад, 4 жіночих монастиря, 3 яких до 1955 р. залишилися два - Браїлівський і Барський. До певної міри нацисти та їх союзники дозволяли відкриття релігійних споруд (у некультових будинках розміщувалося до $60 \%$ церков у Сталінській області, до 50\% - у Харківській, до 40\% - у Полтавській тощо). У Київській єпархії, зокрема, у 1942 p. відкрилося 318 храмів і 8 монастирів. Загалом, станом на жовтень 1943 p. із 9829 діючих православних храмів у СРСР 6500 відкрилися на окупованій території [12, ф.1, оп.12, спр.2, арк. 90].

На тлі «сприяння» відродженню релігійного життя з боку окупаційної влади на захоплених територіях радянське керівництво було змушене переглянути свою політику щодо Православної церкви. Очевидна політична вагомість релігійного питання вимагала від радянського уряду адекватної реакції. Боротьба за віруючих стала ще однією ділянкою ідеологічного протиборства СРСР та нацистської Німеччини. Ураховувалась значна роль Церкви у мобілізації духовних сил народу на відсіч агресорам, іiі патріотична допомога фронту, повернення в ідейно-пропагандистський сфері до історичного традиціоналізму. Представники влади констатували, що «в даний період Руська православна церква займає по відношенню до радянської держави безсумнівну, без тіні підозри, лояльну позицію, веде велику корисну патріотичну роботу» [33, ф. 1, оп. 23, спр. 1640, арк. 63].

Курс на нову релігійну політику передбачав створення відповідних органів, які б виконували функції врегулювання державно-церковних відносин. 14 вересня 1943 р. РНК СРСР прийняв постанову «Про організацію Ради у справах Російської Православної Церкви». Новостворений орган мав при Раднаркомах союзних і автономних республік, обласних виконкомах своїх уповноважених, через яких здійснювався контроль за церковним життям. До повноважень Ради входило, у т.ч., вирішення питання реєстрації релігійних громад та відкриття нових храмів, загальний облік церков.

Нові засади державно-церковних відносин і релігійно-церковного життя були визначені у нормативно-правових актах уряду: постанова РНК СРСР від 7 жовтня 1943 р. «Про права та завдання Ради в справах Російської Православної Церкви й ії уповноважених на місцях»; постанова РНК СРСР від 28 листопада 1943 р. «Про порядок відкриття церков»; від 1 грудня 1944 р. «Про православні церкви й молитовні будинки»; від 22 серпня 1945 р. «Із питань, що стосуються православної церкви і монастирів»; постанова РНК СРСР від 22 серпня 1945 р. «Про деякі зміни в правовому становищі церковних органів», а також у численних листах й інструкціях [26, с. 37-67].

До березня 1944 р. на звільненій території УРСР діяло 2113 приходів РПЦ, 7 чоловічих і 12 жіночих монастирів. До 1 липня 1945 р. в УРСР, за офіційними даними, нараховувалося 6133 православних храмів (близько 40 \% їх дореволюційної чисельності), 15 чоловічих та 27 жіночих 
монастирів. Причому, в Україні зосереджувалось 59,28\% усіх діючих в СРСР церков та молитовних будинків [12, ф. 9, спр. 74, арк. 105-106].

Прикметною, з погляду розуміння тогочасної моделі церковно-державних стосунків, стала директива Наркомату держбезпеки (НКДБ) УРСР від 22 липня 1944 р. № 1341/с. Як повідомлялося, до НКДБ УРСР надходять відомості про те, що у Сумській, Київській, Ворошиловградській та інших областях місцеві органи влади, навіть сільради закривають православні церкви, віддають їх під склади, клуби, контори, що завдає образи релігійним почуттям громадян, створює грунт для провокаційних чуток й перекручень. Органам держбезпеки приписувалося виявляти й розслідувати такі факти, не допускаючи закриття храмів без «відповідного рішення вищих директивних органів», а арешти духовенства проводити лише з санкції НКДБ УРСР [9, с.120].

Хоча після 1945 р. заявки віруючих про відкриття храмів задовольнялися вкрай рідко, кампанія iз знищення (закриття) храмів майже припинилася до нового фронтального наступу (з 1954 р.) на Православну церкву при М.Хрущові, коли в СРСР закрили до 6000 православних храмів, що стало елементом офіційно проголошеної форсованої «побудови комунізму» за життя нинішнього покоління. У 1954-1959 рр. виходить низка спільних постанов ЦК КПРС та уряду СРСР, які регламентували фронтальний адміністративний та пропагандистський наступ на Церкву. Антиконституційні утиски цього періоду боляче вдарили по мережі православних храмів України, адже в республіці знаходилося у 1958 р. до 60\% усіх храмів РПЦ (8091), 46,5\% священників (5962) та 65\% монастирів и скитів. Лише у Полтавскій обл. 31960 до 1965 р. кількість православних молитовних споруд скоротилася з 340 до 52, а з 47 монастирів України залишилося 16 [12, ф.1, оп.12, спр.2, арк.1, 171, 174]. У 1963 р. знов закрили Києво-Печерську Лавру, чиї святині архітектурноісторичного значення зазнали суттєвих руйнувань та занепаду.

Наукова новизна. У статті робиться спроба комплексно дослідити сутність кампанії із нищення православних храмів в єдності іiї ідеологічної, адміністративної, репресивної складової, та, одночасно, у загальному контексті державно-церковних відносин в СРСР, виявити деструктивні наслідки цього процесу для духовно-культурної спадщини українського народу.

Висновки. Від 1917 р. і до кінця 1980-х войовничий державний атеїзм (від прямих фізичних репресій та знищення релігійних споруд та святинь до науково подібного «викриття релігійного мракобісся») став однією із підвалин політики радянської держави та правлячої комуністичної партії, одним із «фронтів» насадження квазімарксистської ідеології, викорінення тяглості духовної національної традиції.

Закриття, брутальне знищення або використання не за призначення православних храмів цілеспрямовано та масово здійснювалося правлячою комуністичною партією та владою 3 метою ліквідації матеріально-культурної бази свобідного віро сповідування, морального придушення віруючих, консолідації населення (передовсім - молоді) навколо агресивної політики державного атеїзму та формування нового типу суспільно-світоглядової ідентичності та політичної лояльності.

Рішення про кампанії із закриття храмів ініціювалися ухвалювалися вищими партійними органами (нерідко - спільно із владними органами) у межах реалізації обов'язкової ідеології, складовою якої був «науковий атеїзм» та «подолання релігійного мракобісся», що розглядалося і як неодмінна складова ментального розриву із «старим світом». По суті, виникло ціле «нормативне поле» нищення церковних споруд, яке згодом суперечило радянським таки конституційним положенням про свободу сумління й відділення Церкви від держави. До директивного характеру цих настанов додавалися ініціативи на місцях, давалися взнаки і деструктивні перетворення у свідомості людей, які пройшли формалізацію офіційного церковного життя в Російській імперії, Першу світову війну, революції, масштабне кровопролиття й бузувірство сторін - учасників громадянської війни 1917-1922 pp.

Мережа православних храмових споруд зазнала величезних збитків. При цьому безповоротно втрачено чимало створених від доби Давньої Русі й Козацько-гетьманської держави перлин храмової архітектури, фресок, оздоблення, богослужбового начиння, постраждали і шановані народом мощі святих угодників. Все це завдало важкого удару по духовно-культурній спадщини, спадкоємності історико-культурних традицій українського народу.

\section{Jimepamypa}

1. Архиепископ Крымский Лука (Войно-Ясинецкий) под надзором ГПУ-НКВД-МГБ: сборник документов. Составитель А. Валякин. Симферополь: ГУ СБУ в АРК, 2010. 128 с.

2. Бабенко Л.Л. Радянські органи державної безпеки в системі взаємовідносин держави і православної церкви в Україні (1918- середина 1950-х рр.). Полтава, 2014. 549 с.

3. Бабенко Л.Л. Участь органів ВЧК-ГПУ у вилученні церковних цінностей на початку 1920-х рp. // 3 архівів ВУЧК-ГПУ-НКВД-КГБ. 2004. №1/2 (22/23). С.410-429. 
4. Бажан О. Репресії серед духовенства та віруючих в УРСР в часи "великого терору": статистичний аспект // 3 архівів ВУЧК-ГПУ-НКВД-КГБ. 2007. №2. С. 12- 29.

5. Бажан О.Г. Випробовування вірою: Боротьба за реалізацію прав і свобод віруючих в Україні в другій половині 1950-х - 1980-ті роки / О. Бажан, Ю. Данилюк. К.: Рідний край, 2000. 330 с.

6. Баран В. Влада і церква: з історії взаємовідносин у 1945-1965 // Сучасність. 1995. №5. С.113-128.

7. Васильева О.Ю. Русская Православная Церковь в политике Советского государства в 1943-1948 гг. М.: ИРИ РАН, 2001. 214 c.

8. Верига В. Конфіскація церковних цінностей в Україні в 1922 р. Н.-Й.; Торонто, 1996.192 с.

9. Вєдєнєєв Д.В., Лисенко О.С. Протидія радянських спецслужб німецькій розвідці й контррозвідці на території України в 1941-1944 pp. // Український історичний журнал. - 2015. - № 1. - С.69-91.

10. Вишиванюк О. Російська православна церква в Україні у 1944-1953 рр. від лібералізації до згортання діяльності // Історія України: маловідомі імена, події, факти: зб. статей. 2004. Вип. 27. С.143-156.

11. Войналович В.А. Партійно-державна політика щодо релігії та релігійних інституцій в Україні в 19401960-х роках: політичний дискурс. К.: Світогляд, 2005. 741 с.

12. Галузевий державний архів Служби безпеки України.

13. Грідіна I.М. Православна Церква в Україні під час Другої світової війни 1939-1945рр.: людський вимір : Дис... канд. іст. наук: 07.00.01 / Грідіна Ірина Миколаївна Донецький національний ун-т. - Донецьк, 2001. 224 c.

14. Сленський В. Державно-церковні взаємини на Україні (1917-1990). К.: Республіканський Центр духовної культури, 1991.72 с.

15. Ігнатуша O.M. Руйнація конфесійної мережі в Україні 20-30-х років XX ст.: реалізація проекту безрелігійного суспільства // Наук. вісн. Волин. держ. ун-ту ім. Лесі Українки. 2003. № 10. С. $32-43$.

16. Киридон А.М. Час випробувань: держава, церква, суспільство в радянській Україні 1917-1930-х років. Тернопіль: Підручники і посібники, 2005. 384 с.

17. Меркатун I. Антирелігійна компанія 50-60-х років на Україні // Український історичний журнал. 1991.№10.C.74-87.

18. Нестуля О.О. Доля церковної старовини в Україні. 1917-1941 рр. К.: Ін-т історії НАН України, 1995. Ч.1. 280 с.; Ч.2. 216 c.

19. Одинцов М.И. Власть и религия в годы войны. Государство и религиозные организации в СССР в годы Великой Отечественной войны 1941-1945 гг. М., 2005. 312 с.

20. Одинцов М. Патриарх Сергий. М.: Молодая гвардия, 2013. 396 с.

21. Пащенко В.О., Киридон А.М. Більшовицька держава і православна церква в Україні. 1917-1930-ті роки. Полтава: АСМI, 2004. 336 с.

22. Пащенко В.О. Православна церква в тоталітарній державі. Україна 1940-початку 1990-х років. Полтава: ACMI, 2005. 631 с.

23. Політичні репресії радянської доби в Україні. Наук.-допоміж. бібліографічний покажч. К.: Арістей, 2008. $684 \mathrm{c}$.

24. Політичний терор і тероризм в Україні: Історичні нариси. К.: Наукова думка, 2002. 952 с.

25. Положення «Про порядок організації, діяльності, звітності і ліквідації релігійних громад та систему обліку адміністративними органами складу релігійних громад та служителів культу» // 3 архівів ВУЧК-ГПУНКВД-КГБ. 2005. № 1/2. С. 61-85.

26. Религиозные организации в СССР: накануне и в годы Великой Отечественной войны (1938-1943 гг.)/ Публ. М.И. Одинцова // Отечественные архивы. 1995.№ 2. С.41-70.

27. Рубльова Н. Репресії проти «церковників» і «сектантів» в УРСР. 1917-1939 рр. // 3 архівів ВУЧКГПУ-НКВД-КГБ. 2007.№ 1. С. 205-219.

28. Силантьев В.И. Большевики и православная церковь на Украине в 20-е годы. Харьков: ХГПУ, 1998. 232 с.

29. Силантьєв В.І. Кампанія по закриттю церков та інших культових споруд в Україні в 20-30-ті роки // Вісник Харківського державного політехнічного університету. 1999. Вип. 20. С.62-72.

30. Тєвікова О. В. Форми та методи антирелігійної боротьби в Україні (1953-1964рр.) / О. В. Тєвікова // Вісник Київського міжнародного університету. Серія «Міжнародні відносини». К: КиМУ, 2009. Вип. 8.С. $292-311$.

31. Центральний державний архів вищих органів влади та управління України.

32. Центральний державний архів громадських об’єднань України.

33. Цыпин Владислав, протоиерей. История Русской Православной Церкви. Синодальный и новейший периоды (1700 -2005). - М.: Сретенский монастырь, 2010. 408 с.

34. Шкаровский М. Русская Православная церковь при Сталине и Хрущеве (государственно-церковные отношения в СССР в 1939-1964 годах). М.: Крутицкое Патриаршее Подворье; Общество любителей церковной истории, 2000. 400 с.

35. Шкаровский М.В. Русская Православная Церковь в XX веке. М.: Вече, 2010. 480 с.

\section{References}

1. Archbishop of Crimean Luka (Voino - Yasinetsky) Under the Supervision of the SPU-NCIA-MSS: a collection of documents. (2010). A. Valiakin (copm.). Simferopol: GU SBU [in Russian].

2. Babenko, L. L. (2014). Soviet Bodies of State Security in the System of Relations between the State and the Orthodox Church in Ukraine (1918 - mid-1950's). Poltava [in Ukrainian]. 
3. Babenko, L. L. (2004). Participation of the Bodies of the Cheka-SPU in the Removal of Church Values in the early 1920's. Z archiviv VUCHK-GPU-NKVD-KGB, №1 / 2 (22/23), 410 - 429 [in Ukrainian].

4. Bazhan, O. (2007). Repressions Among Clergy and Believers in the Ukrainian SSR during the "Great Terror": the statistical aspect. Z archiviv VUCHK-GPU-NKVD-KGB, №2. 12-29 [in Ukrainian].

5. Bazhan ,O. \& Danylyuk, Y. (2000). Testing byFaith: Fighting for the Realization of the Believers' Rights and Freedoms in Ukraine in the second half of the 1950s - 1980s Kyiv: Ridny kray [in Ukrainian].

6. Baran, B. (1995). Government and Church: From the History of Relations in 1945-1965.Suchasnist, №5, 113 -128 [in Ukrainian].

7. Vasilyeva, O.Yu. (2001). Russian Orthodox Church in the Policy of the Soviet state in 1943-1948. Moscow: IRI RAS [in Russian]. Ukrainian].

8. Verigha, V. (1996). Confiscation of the Church Values in Ukraine in 1922. New York; Toronto [in

9. Vedeneev, D.V. \& Lysenko, O.E. (2015). Opposition to Soviet Intelligence Services for German Intelligence and Counterintelligence on the Territory of Ukraine in 1941-1944. Ukrainskiy Istorychnyi Journal, 2015, No. 1, P.69 91 [in Ukrainian].

10. Vyshyvaniuk, O. (2004). Russian Orthodox Church in Ukraine in 1944-1953 from Liberalization to stopping its activity. Istoria Ukrainy: malovidomi imena, podii, fakty, 27, 143 - 156[in Ukrainian].

11. Voinalovych, V. (2005). The Party and State Policy on Religion and Religious Institutions in Ukraine in the 1940 - 1960s: political discourse. Kyiv: Svitogliad [in Ukrainian].

12. Specialized State Archive of the Security Service of Ukraine [in Ukrainian].

13. Gridin, I. M. (2001). The Orthodox Church in Ukraine during the Second World War of 1939-1945: Human Dimension. Candidate's thesis. Donetsk [in Ukrainian].

14. Yelensky, V. (1991). State-Church Relations in Ukraine (1917-1990). Kyiv: Republicanskyi Centr Dukhovnoi Cultury [in Ukrainian].

15. Ignatusha, O. M. (2003). Destruction of the Confessional Network in Ukraine in the 20-30th years of the 20th Century: implementation of the project of a nonreligious society. // Nauk. visnyk Volynskogo derzhavnogoe un-tu imeni Lesi Ukrainky, No. 10, 32 - 43[in Ukrainian]. Ukrainian].

16. Kyrydon, A. M. (2005). Crucial Time: State, Church, Society in Soviet Ukraine 1917 - 1930. Ternopil [in

17. Merkatun, I. (1991). Antireligious Campaign of the 1950s and 1960s in Ukraine. Ukrainskyi Istorychnyi Journal, №10. 74 - 87 [in Ukrainian].

18. Nestulia, O.O. (1995). The Destiny of the Church Antiquity in Ukraine. 1917 - 1941. Institute of History of the National Academy of Sciences of Ukraine, Ch.1. Part 2 [in Ukrainian].

19. Odintsov, M. I. (2005). Power and Religion during the Years of War. State and Religious Organizations in the USSR during the Years of the Great Patriotic War of 1941-1945. Moscow [in Russian].

20. Odintsov, M. (2013). Patriarch Sergiy. Moscow [in Russian].

21. Paschenko, V.O. \& Kyrydon A. M. (2004). Bolshevik State and Orthodox Church in Ukraine. 1917 - 1930 s. Poltava: ASMI [in Ukrainian].

22. Paschenko, V.O. (2005). Orthodox Church in the Totalitarian State. Ukraine 1940 - early 1990's. Poltava: ASMI [in Ukrainian].

23. Political Repressions of the Soviet era in Ukraine. Scientific -assistant bibliographical index. (2008). Kyiv: Ariste [in Ukrainian].

24. Political Terror and Terrorism in Ukraine: historical essays. (2002). Kyiv: Naukova Dumka [in Ukrainian].

25. On the order of organization, activity, reporting and liquidation of religious communities and the system of registration by administrative authorities of the composition of religious communities and ministers of worship. (2005). $\mathrm{Z}$ archiviv VUCHK-GPU-NKVD-KGB, No. 1/2, 61 - 85 [in Ukrainian].

26. Religious organizations in the USSR: the day before and during the Great Patriotic War (1938-1943) / Public. WE. Odintsova // Domestic archives. 1995.№ 2. C.41-70.

27. Rubliova, N. (2007). Repressions against "Churchmen" and "Sectarians" in the Ukrainian SSR. 1917 - 1939 biennium.$Z$ archiviv of the VUCHK-GPU-NKVD-KGB, No. 1, 205 - 219 [in Ukrainian]. Russian].

28. Silantyev, V. I. (1998). Bolsheviks and the Orthodox Church in Ukraine in the 20's. Kharkiv: KhGPU [in

29. Silantyev, V. I. (1999). Campaign for the Elimination of Churches and other Religious Buildings in Ukraine in the $1920-30$ 's. Visnyk Kharkivskogo Derzhavnogo Polytechnichnogo Universytetu, 20. 62 - 72 [in Ukrainian].

30. Tevikova, O. V. (2009). Forms and Methods of the Anti-religious Struggle in Ukraine (1953 - 1964). Visnyk

Kyivskogo Mizhnarodnogo Universytetu. International Relations. Kyiv: KMU, 8, 292 - 311 [in Ukrainian].

31. Central State Archive of the Supreme Power and Administration of Ukraine.

32. Central State Archive of Public Associations of Ukraine.

33. Tsypin, V. (2010). History of the Russian Orthodox Church: Synodal and Recent Periods(1700 -2005). Moscow : Izdatelstvo Sretenskogo Monasteria [in Russian].

34. Shkarovsky, M. (2000). Russian Orthodox Church of Stalin and Khrushchev (state-church relations in the USSR in 1939 - 1964). Moscow: Krutitskoye Patriarchal [in Russian].

35. Shkarovskyi, M. V. (2010). Russian Orthodox Church in XX century. Moscow : Veche, Lepta [in Russian]. 